\title{
Annual Transportation Report for Radioactive Waste Shipments to and from the Nevada Test Site
}

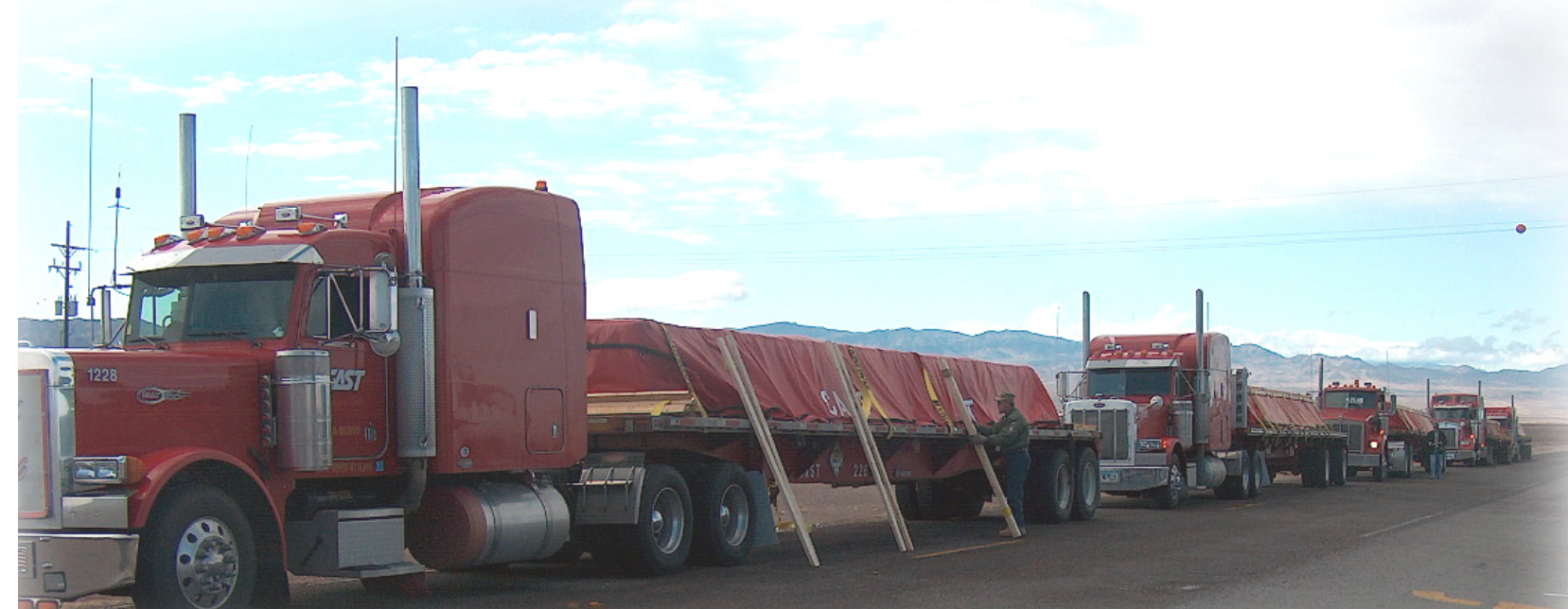

Fiscal Year 2008

February 2009

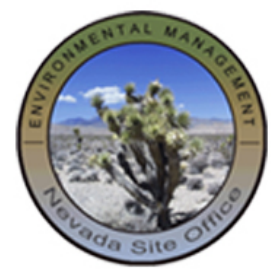

U.S. Department of Energy

National Nuclear Security Administration

Nevada Site Office 
Available for sale to the public from-

U.S. Department of Commerce

National Technical Information Service

5285 Port Royal Road

Springfield, VA 22161

Phone: 800.553 .6847

Fax: 703.605.6900

Email: orders@ntis.gov

Online ordering: http://www.ntis.gov/ordering.htm

Available electronically at http://www.osti.gov/bridge

Available for a processing fee to U.S. Department of Energy and its contractors, in paper, from-

U.S. Department of Energy

Office of Scientific and Technical Information

P.O. Box 62

Oak Ridge, TN 37831-0062

Phone: 865.576.8401

Fax: 865.576.5728

Email: reports@adonis.osti.gov 


\title{
ANNUAL TRANSPORTATION REPORT FY 2008
}

\author{
Radioactive Waste Shipments \\ to and from the Nevada Test Site (NTS)
}

February 2009

United States Department of Energy

National Nuclear Security Administration

Nevada Site Office

Las Vegas, Nevada 
This page intentionally left blank 


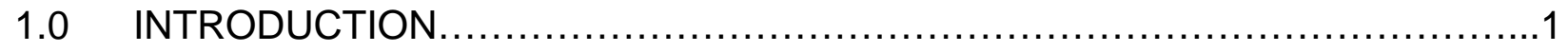

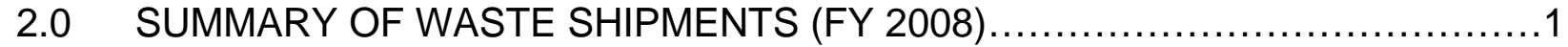

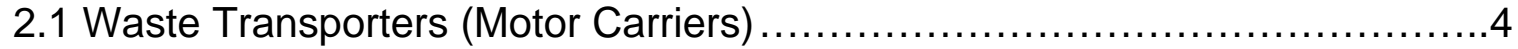

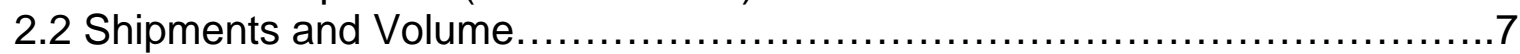

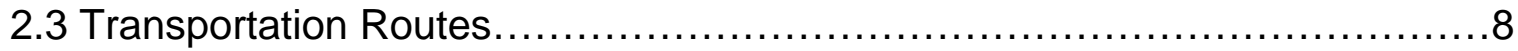

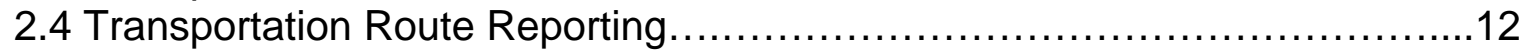

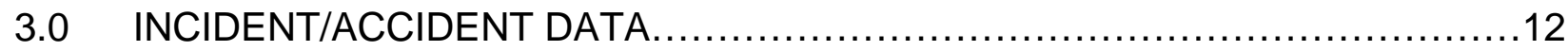

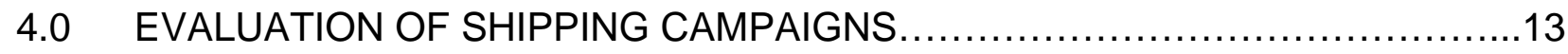

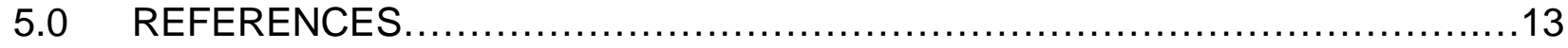

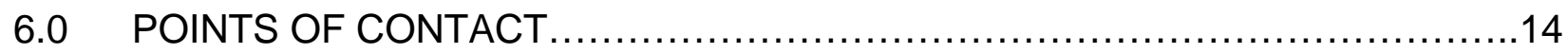

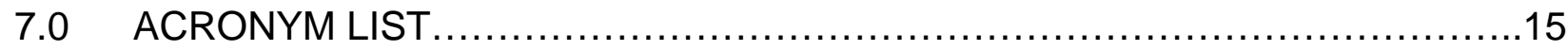

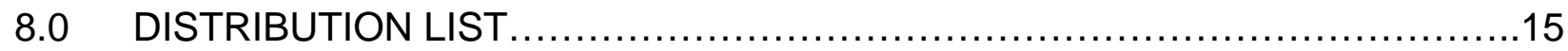


This page intentionally left blank 


\subsection{INTRODUCTION}

In February 1997, the U.S. Department of Energy (DOE), Nevada Operations Office (now known as the Nevada Site Office) issued the Mitigation Action Plan which addressed potential impacts described in the "Final Environmental Impact Statement for the Nevada Test Site and Off-Site Locations in the State of Nevada" (DOE/EIS 0243). The U.S. Department of Energy, Nevada Operations Office committed to several actions, including the preparation of an annual report, which summarizes waste shipments to and from the Nevada Test Site (NTS) Radioactive Waste Management Site (RWMS) at Area 5 and Area 3. No shipments were disposed of at Area 3 in fiscal year (FY) 2008. This document satisfies requirements regarding low-level radioactive waste (LLW) and mixed low-level radioactive waste (MLLW) transported to or from the NTS during FY 2008. No transuranic (TRU) waste shipments were made from or to the NTS during FY 2008.

This report has been prepared in accordance with the specifications contained in Section 4.1.1 (Commitments) of the "NTS Environmental Impact Statement, Mitigation Action Plan" (February 1997). Tabular summaries are provided which include the following data:

- $\quad$ Sources of and carriers for LLW and MLLW shipments to/and or from the NTS;

- $\quad$ Number and external volume of LLW and MLLW shipments;

- Identification of highway routes used by carriers; and

- Incident/accident data applicable to LLW and MLLW shipments.

\subsection{SUMMARY OF WASTE SHIPMENTS (FY 2008)}

Inbound/Off-site LLW

A total of $1,088,117 \mathrm{ft}^{3}$ of LLW was disposed at the NTS in FY 2008, consisting of 1,221 inbound/off-site shipments, from 20 approved generators. These shipments were transported on 14 approved motor carriers (including government vehicles).

Inbound/Off-site MLLW

A total of $43,845 \mathrm{ft}^{3}$ of MLLW was received at the NTS in 99 inbound/off-site shipments in FY 2008, from seven approved generator. These shipments were transported on nine approved motor carriers.

Total Inbound/Off-site LLW and MLLW

A total of 1,131,962 $\mathrm{ft}^{3}$ of LLW was disposed at the NTS in FY 2008 by 20 approved off-site generators in 1,320 shipments, transported on 16 approved motor carriers.

On-site LLW

Two approved on-site generators disposed $40,981 \mathrm{ft}^{3}$ of LLW in 45 on-site transfers. Government (contractor) vehicles were used for these transfers. 
On-site MLLW

Three on-site transfers accounted for $1,713 \mathrm{ft}^{3}$ of MLLW being disposed by one (1) on-site generator.

Total On-site LLW/MLLW

Fourty-Eight on-site transfers accounted for 42,694 $\mathrm{ft}^{3}$ of LLW/MLLW being disposed by two on-site generators.

Outbound/Off-site LLW

No outbound/off-site shipments of LLW were made by NTS tenants.

One shipment $\left(1,359 \mathrm{ft}^{3}\right)$ of LLW originally shipped by the Portsmouth Gaseous Diffusion Plant was returned by the generator using an approved carrier.

Outbound/Off-site MLLW

Four outbound shipments containing $352 \mathrm{ft}^{3}$ of MLLW were made from the NTS. National Security Technologies, LLC (NSTec), the Management and Operations contractor at the NTS, completed two shipments to Materials \& Energy Corporation and two shipments to Diversified Scientific Services Inc, both located in Tennessee. These shipments were transported by approved carriers.

One package from EnergX shipment FWM07001 $\left(170 \mathrm{ft}^{3}\right)$ was returned to generator via an approved motor carrier in November 2007.

Outbound/Off-site Transuranic (TRU) Waste

No TRU waste shipments were made from the NTS to WIPP in FY 2008.

Table 1 provides a summary of inbound, outbound, and on-site shipments for FY 2008. Names and codes for approved generators and carriers used in this report are located in Tables 2 and 3, respectively.

Table 1. FY 2008 NTS Inbound, Outbound and On-site Summary Information

\begin{tabular}{|c|c|c|c|c|c|}
\hline Inbound & $\begin{array}{c}\text { Off-site } \\
\text { Generators }\end{array}$ & $\begin{array}{c}\text { NTS } \\
\text { Generators }\end{array}$ & $\begin{array}{c}\text { Approved } \\
\text { Carriers }\end{array}$ & Shipments & Volume $\mathrm{ft}^{3}$ \\
\hline LLW (off-site) & 19 & 1 & 14 & 1,221 & $1,088,117$ \\
\hline MLLW (off-site) & 7 & 0 & 9 & 99 & 43,845 \\
\hline LLW (on-site) & 0 & 2 & 1 & 45 & 40,981 \\
\hline MLLW (on-site) & 0 & 1 & 1 & 3 & 1,713 \\
\hline Outbound & $\begin{array}{c}\text { Off-site } \\
\text { Generators }\end{array}$ & $\begin{array}{c}\text { NTS } \\
\text { Generators }\end{array}$ & $\begin{array}{l}\text { Approved } \\
\text { Carriers }\end{array}$ & Shipments & Volume $\mathrm{ft}^{3}$ \\
\hline LLW 1/ & 1 & 0 & 1 & 1 & 1,359 \\
\hline MLLW 2/ & 1 & 1 & 2 & 5 & 522 \\
\hline
\end{tabular}


Table 2. List of Approved Generators Shipping To/From/On the NTS

\begin{tabular}{|l|l|c|}
\hline & \multicolumn{1}{|c|}{ APPROVED GENERATOR, STATE } & $\begin{array}{c}\text { GENERATOR } \\
\text { CODE }\end{array}$ \\
\hline 1 & ARGONNE NATIONAL LABORATORY, IL & AE \\
\hline 2 & BECHTEL JACOBS OAK RIDGE, TN & OR \\
\hline 3 & BOEING ROCKETDYNE, CA & BN \\
\hline 4 & BROOKHAVEN NATIONAL LABORATORY, NY & BR \\
\hline 5 & BWXT Y-12 PLANT, TN & BW \\
\hline 6 & DURATEK, OAK RIDGE, TN & DR \\
\hline 7 & ENERGX, TN & $\mathrm{FW}$ \\
\hline 8 & IDAHO NATIONAL LABORATORY, ID & $\mathrm{IN}$ \\
\hline 9 & LAWRENCE LIVERMORE NATIONAL LABORATORY, CA & $\mathrm{LL}$ \\
\hline 10 & NATIONAL SECURITY TECHNOLOGIES, NV & $\mathrm{DP}$ \\
\hline 11 & NUCLEAR FUEL SERVICES, TN & $\mathrm{NF}$ \\
\hline 12 & PADUCAH GASEOUS DIFFUSION PLANT, KY & $\mathrm{PD}$ \\
\hline 13 & PANTEX PLANT, TX & $\mathrm{PX}$ \\
\hline 14 & PERMAFIX (M\&EC), TN & $\mathrm{PF}$ \\
\hline 15 & PORTSMOUTH GASEOUS DIFFUSION PLANT, OH & $\mathrm{PO}$ \\
\hline 16 & PRINCETON PLASMA PHYSICS LABORATORY, NJ & $\mathrm{PL}$ \\
\hline 17 & SANDIA NATIONAL LABORATORIES, NM & $\mathrm{SA}$ \\
\hline 18 & STOLLER-NAVARRO JOINT VENTURE & $\mathrm{IT}$ \\
\hline 19 & UT-BATTELLE, TN & $\mathrm{OL}$ \\
\hline 20 & WASHINGTON SAVANNAH RIVER COMPANY, SC & $\mathrm{SR}$ \\
\hline 21 & WEST VALLEY DEMONSTRATION PROJECT, NY & $\mathrm{WV}$ \\
\hline
\end{tabular}

Table 3. List of Approved Motor Carriers Utilized in FY 2008

\begin{tabular}{|c|l|c|}
\hline \multicolumn{1}{|c|}{ APPROVED MOTOR CARRIER } & $\begin{array}{c}\text { CARRIER } \\
\text { CODE }\end{array}$ \\
\hline 1 & AJ METLER & MAJH \\
\hline 2 & BUFFALO FUEL COMPANY & BFUI \\
\hline 3 & CAST TRANSPORTATION & COLO \\
\hline 4 & FLUID TRANSPORTS & FLAI \\
\hline 5 & GOVERNMENT VEHICLE & GT+ \\
\hline 6 & HITTMAN TRANSPORT & HITT \\
\hline 7 & HUBBARD TRUCKING & HUB+ \\
\hline 8 & INTERSTATE VENTURES & ITSV \\
\hline 9 & LANDSTAR RANGER & LRGR \\
\hline 10 & MP ENVIRONMENTAL & MPES \\
\hline 11 & R \& R TRUCKING & RRUK \\
\hline 12 & RSB LOGISTICS & RSBI \\
\hline 13 & SAVAGE LOGISTICS, LLC & SVGH \\
\hline 14 & SOUTHERN FREIGHT LOGISITICS & SFLG \\
\hline 15 & SPECIALTY TRANSPORT & SPCN \\
\hline 16 & TRI-STATE MOTOR TRANSIT & TSMT \\
\hline
\end{tabular}




\subsection{Waste Transporters (Motor Carriers)}

Generators often use more than one motor carrier to facilitate their shipments. Table 4 (a.-b.) identifies each generator and the corresponding carrier(s) utilized for transport of inbound, off-site LLW and MLLW shipments. Table 5 identifies each generator and the corresponding carrier(s) utilized for transport of outbound, off-site shipments of LLW and MLLW. Table 6 identifies each generator and the corresponding carrier(s) utilized for transport of on-site transfers of LLW and MLLW. Motor carriers operate in compliance with regulations located in Title 49 Code of Federal Regulations, "Transportation," and are selected by the generator.

A total of 146 inbound LLW shipments were transported intermodally in FY 2008. These shipments were first transported from their origination points (West Valley Demonstration Project and Nuclear Fuel Services) via rail to a rail siding in Parker, Arizona where they were then transloaded and transported via an approved motor carrier to the NTS. 
Table 4a. Waste Transporters Utilized by Generators for Inbound LLW Shipments (number of shipments)

\begin{tabular}{|c|c|c|c|c|c|c|c|c|c|c|c|c|c|c|c|c|c|c|c|c|c|}
\hline & $\mathrm{AE}$ & $\mathrm{BN}$ & BR & BW & DP & DR & FW & IN & LL & NF & $\mathrm{OL}$ & OR & PD & PF & $\mathrm{PL}$ & $\mathrm{PO}$ & $\mathrm{PX}$ & SA & SR & WV & TOTAL \\
\hline BFUI & & & & & & & & & & & & & & & & & & & & 60 & 60 \\
\hline FLAI & & & & & & & & & & & & & & & & 43 & 2 & 5 & & & 50 \\
\hline GT+ & & & & & 1 & & & & 7 & & & & & & & & & & & & 8 \\
\hline HITT & & & & 18 & & 3 & & & 1 & & & & & 31 & & 21 & & & 1 & & 75 \\
\hline HUB+ & & & & & & & & & & & & & & & & 39 & & & & & 39 \\
\hline ITSV & & & 54 & 2 & & & 2 & & & & & & & & & & & & & 75 & 133 \\
\hline LRGR & & & & & & & & & & & & & & & & & & & 76 & & 76 \\
\hline MAJH & & & & 129 & & & & & & 22 & 1 & 53 & 10 & 29 & & 39 & & & & & 283 \\
\hline MPES & & 1 & & & & & & & & & & & & & & & & & & & 1 \\
\hline RRUK & & & & & & & & & & & & 1 & & 7 & & 268 & & & & & 276 \\
\hline RSBI & & & 4 & & & & & & & & & & & & & & & & & & 4 \\
\hline SFLG & & & & & & & & & & 25 & & & & & & & & & & & 25 \\
\hline SPCN & & & & & & & & & & & & & 1 & & & & & & & & 1 \\
\hline TSMT & 1 & & & 32 & & & & 71 & 23 & 24 & & & & 1 & 1 & 37 & & & & & 190 \\
\hline & 1 & 1 & 58 & 181 & 1 & 3 & 2 & 71 & 31 & 71 & 1 & 54 & 11 & 68 & 1 & 447 & 2 & 5 & 77 & 135 & 1,221 \\
\hline
\end{tabular}

Table 4b. Waste Transporters Utilized by Generators for Inbound MLLW Shipments (number of shipments)

\begin{tabular}{|l|r|r|r|r|r|r|r|r|}
\hline & BN & BW & IN & PF & PO & SA & SR & TOTAL \\
\hline COLO & & & & 34 & & & & $\mathbf{3 4}$ \\
\hline FLAI & & & & & & 3 & & $\mathbf{3}$ \\
\hline HITT & & & & 18 & & & 2 & $\mathbf{2 0}$ \\
\hline HUB+ & & & & & 3 & & & $\mathbf{3}$ \\
\hline MAJH & & 2 & & & & & & $\mathbf{2}$ \\
\hline MPES & 1 & & & & & & & $\mathbf{1}$ \\
\hline RRUK & & & & 5 & & & & $\mathbf{5}$ \\
\hline SVGH & & & & 15 & & & & $\mathbf{1 5}$ \\
\hline TSMT & & & 15 & 1 & & & & $\mathbf{1 6}$ \\
\hline & $\mathbf{1}$ & $\mathbf{2}$ & $\mathbf{1 5}$ & $\mathbf{7 3}$ & $\mathbf{3}$ & $\mathbf{3}$ & $\mathbf{2}$ & $\mathbf{9 9}$ \\
\hline
\end{tabular}


Table 5. Carriers Utilized by NTS Approved Generators for Outbound Shipments

\begin{tabular}{|l|c|c|c|}
\hline & DP & FW & PO \\
\hline RRUK & & & $1 \underline{3 l}$ \\
\hline MAJH & & $1 \underline{4} I$ & \\
\hline COLO & 4 & & \\
\hline
\end{tabular}

3/ Portsmouth Gaseous Diffusion Plant LLW shipment POL08205 was refused and returned to generator via R \& R Trucking (RRUK). 4/ One package of MLLW from EnergX (shipment FWM07001 at $170 \mathrm{ft}^{3}$ ) was returned to generator via AJ Metler (MAJH).

\section{Table 6. Waste Transporters Utilized by NTS Generators for On-site Transfers}

\begin{tabular}{|c|c|c|}
\hline & DP & IT \\
\hline GT+ & 42 & 6 \\
\hline
\end{tabular}




\subsection{Shipments and Volume}

Table 7 (a.-f.) provides a summary of all LLW, MLLW, and TRU waste shipments, including volume, to and from the NTS during FY 2008.

Table 7a. Shipments and Volumes of LLW Transported to the NTS (FY 2008)

\begin{tabular}{|c|c|c|c|c|c|c|}
\hline \multirow{2}{*}{$\begin{array}{c}\text { Off-site Inbound Low Level Waste } \\
\text { Shipments } \\
\text { Generator Code } \\
\end{array}$} & \multicolumn{5}{|c|}{ Shipments by Quarter } & \multirow{2}{*}{$\begin{array}{c}\text { Volume } \\
(\mathrm{ft} 3)\end{array}$} \\
\hline & $1 \mathrm{st}$ & 2nd & $3 r d$ & $4^{\text {th }}$ & Total & \\
\hline $\mathrm{AE}$ & & & & 1 & 1 & 830 \\
\hline $\mathrm{BN}$ & & 1 & & & 1 & 153 \\
\hline $\mathrm{BR}$ & & & 29 & 29 & 58 & 11,371 \\
\hline BW & 26 & 36 & 43 & 76 & 181 & 220,296 \\
\hline $\mathrm{DP}$ & & 1 & & & 1 & 8 \\
\hline $\mathrm{DR}$ & & & 2 & 1 & 3 & 940 \\
\hline $\mathrm{FW}$ & & 1 & & 1 & 2 & 5,116 \\
\hline IN & 7 & 18 & 30 & 16 & 71 & 27,032 \\
\hline $\mathrm{LL}$ & 6 & 7 & 16 & 2 & 31 & 44,658 \\
\hline $\mathrm{NF}$ & 17 & 24 & 14 & 16 & 71 & 79,143 \\
\hline $\mathrm{OL}$ & & & & 1 & 1 & 5 \\
\hline OR & 12 & 19 & 5 & 18 & 54 & 72,148 \\
\hline $\mathrm{PD}$ & & 1 & 4 & 6 & 11 & 6,043 \\
\hline $\mathrm{PF}$ & 20 & 13 & 23 & 12 & 68 & 31,780 \\
\hline $\mathrm{PL}$ & & & & 1 & 1 & 138 \\
\hline $\mathrm{PO}$ & 77 & 78 & 86 & 206 & 447 & 410,969 \\
\hline $\mathrm{PX}$ & & & & 2 & 2 & 2,002 \\
\hline SA & & 2 & 1 & 2 & 5 & 4,917 \\
\hline SR & 1 & & & 76 & 77 & 102,491 \\
\hline WV & 117 & 5 & & 13 & 135 & 68,077 \\
\hline Total Shipments & 283 & 206 & 253 & 479 & 1,221 & $1,088,117$ \\
\hline
\end{tabular}

Table 7b. Shipments and Volumes of MLLW Transported to the NTS (FY 2008)

\begin{tabular}{|c|c|c|c|c|c|c|}
\hline $\begin{array}{l}\text { Off-site Inbound Mixed Low Level Waste } \\
\text { Shipments }\end{array}$ & \multicolumn{5}{|c|}{ Shipments by Quarter } & \multirow{2}{*}{$\begin{array}{l}\text { Volume } \\
\text { (ft3) }\end{array}$} \\
\hline Generator Code & $1 \mathrm{st}$ & $2 \mathrm{nd}$ & $3 \mathrm{rd}$ & $4^{\text {th }}$ & Total & \\
\hline $\mathrm{BN}$ & & 1 & & & 1 & 110 \\
\hline BW & & 1 & & 1 & 2 & 4,879 \\
\hline IN & 6 & 3 & 3 & 3 & 15 & 4,589 \\
\hline $\mathrm{PF}$ & 2 & 9 & 26 & 36 & 73 & 30,004 \\
\hline $\mathrm{PO}$ & & & 3 & & 3 & 3,099 \\
\hline SA & & 1 & 1 & 1 & 3 & 422 \\
\hline $\mathrm{SR}$ & 2 & & & & 2 & 742 \\
\hline Total Shipments & 10 & 15 & 33 & 41 & 99 & 43,845 \\
\hline
\end{tabular}


Table 7c. Transfers and Volumes of LLW Transported on the NTS (FY 2008)

\begin{tabular}{|c|c|c|c|c|c|c|}
\hline On-site Low Level Waste Transfers & \multicolumn{5}{|c|}{ Shipments by Quarter } & Volume \\
\hline Generator Code & $1 \mathrm{st}$ & $2 \mathrm{nd}$ & 3 rd & $4^{\text {th }}$ & Total & $(\mathrm{ft} 3)$ \\
\hline DP & 6 & 20 & 1 & 12 & 39 & 35,819 \\
\hline IT & 5 & 1 & 0 & 0 & 6 & 5,162 \\
\hline Total & 11 & 21 & 1 & 12 & 45 & 40,981 \\
\hline
\end{tabular}

Table 7d. Transfers and Volumes of MLLW Transported on the NTS (FY 2008)

\begin{tabular}{|c|c|c|c|c|c|c|}
\hline On-site Mixed Low-Level Waste Transfers & \multicolumn{5}{|c|}{ Shipments by Quarter } & Volume \\
\hline Generator Code & $1 \mathrm{st}$ & 2nd & $3^{\text {rd }}$ & $4^{\text {th }}$ & Total & $(\mathrm{ft} 3)$ \\
\hline DP & 0 & 1 & 2 & 0 & 3 & 1,713 \\
\hline Total & 0 & 1 & 2 & 0 & 3 & 1,713 \\
\hline
\end{tabular}

Table 7e. Shipments and Volumes of LLW Transported from the NTS (FY 2008)

\begin{tabular}{|c|c|c|c|c|c|c|}
\hline Outbound Low-Level Waste Shipments & \multicolumn{5}{|c|}{ Shipments by Quarter } & \multirow{2}{*}{$\begin{array}{c}\text { Volume } \\
(\mathrm{ft} 3)\end{array}$} \\
\hline Generator Code & $1 \mathrm{st}$ & 2nd & $3 r d$ & $4^{\text {th }}$ & Total & \\
\hline $\mathrm{PO}$ & 0 & 0 & 0 & 1 & 1 & 1,359 \\
\hline Total & 0 & 0 & 0 & 1 & 1 & 1,359 \\
\hline
\end{tabular}

Table 7f. Shipments and Volumes of MLLW Transported from the NTS (FY 2008)

\begin{tabular}{|l|c|c|c|c|c|c|c|}
\hline \multicolumn{2}{c|}{$\begin{array}{c}\text { Outbound Mixed Low-Level Waste } \\
\text { Shipments }\end{array}$} & \multicolumn{5}{c|}{ Shipments by Quarter } & \multirow{2}{*}{$\begin{array}{c}\text { Volume } \\
\text { (ft3) }\end{array}$} \\
\hline & $1 \mathrm{st}$ & $2 \mathrm{nd}$ & $3 \mathrm{rd}$ & $4^{\text {th }}$ & Total & $\mathbf{3 5 2}$ \\
\hline $\mathrm{DP}$ & 0 & 2 & 0 & 2 & 4 & $\mathbf{1 7 0}$ \\
\hline $\mathrm{FW}$ & 1 & 0 & 0 & 0 & 1 & $\mathbf{5 2 2}$ \\
\hline
\end{tabular}

\subsection{Transportation Routes}

Twenty out-of-state approved generators shipped LLW and MLLW to the NTS for disposal in FY 2008. Table 8 provides specific routes utilized by each generator and the number of shipments in FY 2008. Figures 1 and 2 provide graphical interpretations of the general cross country and regional transportation routes, respectively. 
Figure 1 - FY 2008 National

Low-Level, Mixed Low-Level, and Transuranic Waste General Transportation Routes to/from the Nevada Test Site

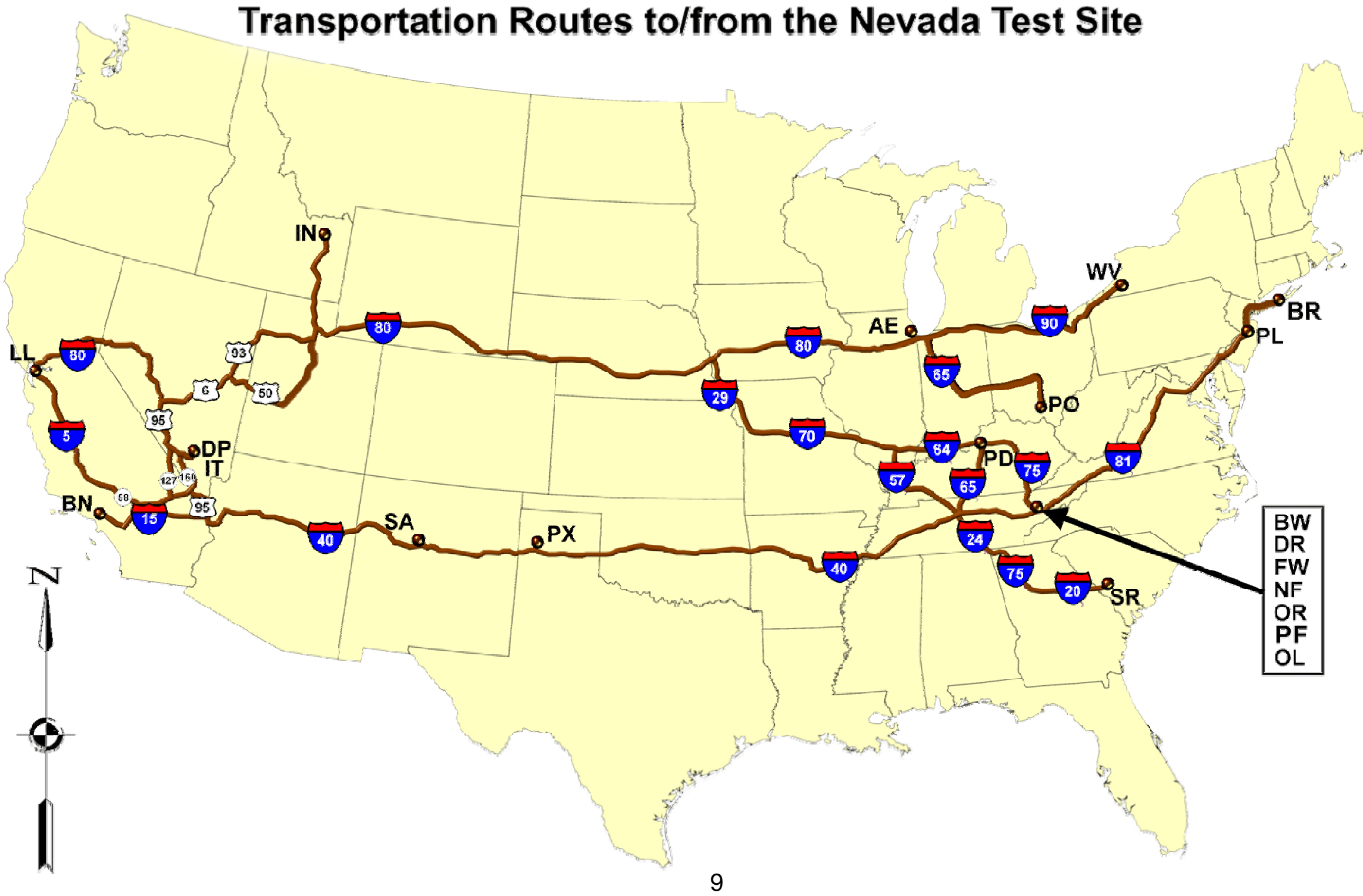




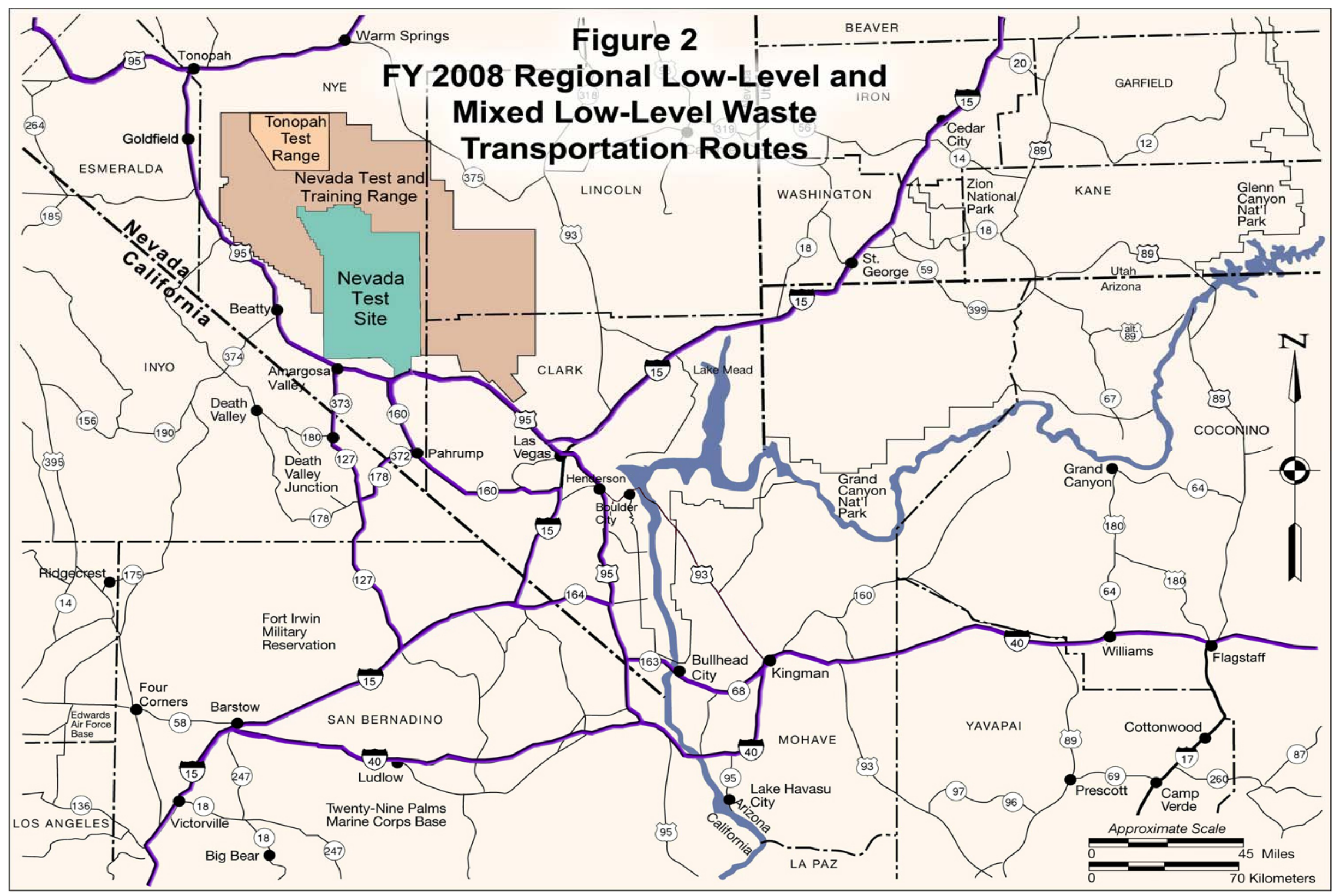


Table 8. Shipment Summary of Off-site, Inbound Regional Routes for FY 2008

\begin{tabular}{|c|c|c|c|c|c|c|c|c|c|c|c|c|c|c|c|c|c|c|c|c|c|}
\hline DESCRIPTION & $\mathrm{AE}$ & $\mathrm{BN}$ & $\mathrm{BR}$ & BW & DP & DR & $\mathrm{FW}$ & IN & LL & NF & $\mathrm{OL}$ & OR & PD & $\mathrm{PF}$ & $\mathrm{PL}$ & $\mathrm{PO}$ & $\mathrm{PX}$ & SA & SR & WV & TOTAL \\
\hline I-15, CA-127, CA-178, NV-372, NV-160, US-95 & & 2 & & & & & & & & & & & & & & & & & & & 2 \\
\hline I-15, CA-127, NV-373, US-95 & & & & & & & & & 28 & & & & & & & & & & & & 28 \\
\hline I-40, I-15, CA-127, NV-373, US-95 & & & & 1 & & & & 2 & & & & & & & & 1 & & & & & 4 \\
\hline $\mathrm{I}-40, \mathrm{I}-15, \mathrm{NV}-160$, US-95 & & & & & & & & & 1 & & & & & & & 3 & & & 7 & & 11 \\
\hline I-40, US-93, AZ-68, NV-163, US-95, NV-164, I-15, NV-160, US-95 & & & 3 & 22 & & & & 2 & & & & 13 & & & & & & & 6 & & 46 \\
\hline I-40, US-95, NV-164, I-15, CA-127, CA-178, NV-372, NV-160, US-95 & & & & & & & & & & & & & & 1 & & & & & & & 1 \\
\hline I-40, US-95, NV-164, I-15, CA-127, NV-373, US-95 & & & & 2 & & & & & & & & & & & & & & & & & 2 \\
\hline I-40, US-95, NV-164, I-15, NV-160, US-95 & & & 51 & 157 & 1 & 3 & 2 & 21 & 2 & $71^{*}$ & 1 & 41 & 11 & 91 & 1 & 445 & 2 & 8 & 66 & $75^{*}$ & 1,049 \\
\hline I-80, US-93-ALT, US-6, US-95 & 1 & & & 1 & & & & 56 & & & & & & 33 & & 1 & & & & 60 & 152 \\
\hline I-80, US-95 (WINNEMUCCA) & & & & & & & & 1 & & & & & & & & & & & & & 1 \\
\hline US-50, US-6/50, US-6, US-95 & & & 4 & & & & & & & & & & & & & & & & & & 4 \\
\hline US-93, I-80, US-93-ALT, US-93, US-6, US-95 & & & & & & & & 3 & & & & & & 5 & & & & & & & 8 \\
\hline US-93, US-6, US-95 & & & & & & & & 1 & & & & & & 11 & & & & & & & 12 \\
\hline & 1 & 2 & 58 & 183 & 1 & 3 & 2 & 86 & 31 & 71 & 1 & 54 & 11 & 141 & 1 & 450 & 2 & 8 & 79 & 135 & 1,320 \\
\hline
\end{tabular}

* These shipments were shipped intermodally to Parker, AZ then transported via motor carrier to the NTS. 


\subsection{Transportation Route Reporting}

As a result of obligations made by former DOE Secretary Richardson, the transportation of inbound LLW shipments through the Las Vegas I-15 and US-95 Interchange (Spaghetti Bowl) has substantially decreased since FY 2000.

The U.S. Department of Energy, National Nuclear Security Administration Nevada Site Office (NNSA/NSO) continues to engage in discussions with the generators regarding avoidance of the Spaghetti Bowl. The NTS Waste Acceptance Criteria includes wording requiring generators to notify their carriers to avoid this area.

No LLW/MLLW shipments were transported through the Spaghetti Bowl during FY 2008.

Due to the events of September 11, 2001, tractor trailers are no longer allowed to travel across Hoover Dam. NNSA/NSO continues to honor an additional obligation made by former Secretary Richardson, and endorsed by the current administration, by preparing quarterly reports disclosing which routes transporters used to reach the NTS. These reports may be found on the Internet at http://www.nv.doe.gov/emprograms/environment/wastemanagement/quarterlyrepo rts.aspx

\subsection{INCIDENTIACCIDENT DATA}

For the purpose of this report, an incident is defined as a traffic-related accident, a load shift, or a reported leaking/breached package which occurs during transportation.

Generators are instructed to notify the NNSA/NSO Assistant Manager of Environmental Management whenever a discrepancy, non-compliance, or inadequate performance is identified; or if a transportation incident or emergency situation occurs. There was one U.S. Department of Transportation reportable transportation incident involving LLW or MLLW being transported to the NTS in FY 2008.

- A vehicle transporting LLW to the NTS was involved in a single vehicle accident on the ramp from North-bound Interstate 15 and Nevada State Route 160. The tractor and trailer rolled on to its side at slow speed. The package retained its contents. After the scene was released by law enforcement, the package was transferred to another vehicle (same carrier) and was delivered to the NTS without further incident.

NSTec personnel control NNSA/NSO waste receipt and disposal activities at the NTS and are responsible for notifying appropriate personnel regarding any noncompliant or refused radioactive waste shipments. NSTec personnel also immediately notify generators in the event of any shipping paper discrepancies. Below is a summary of issues observed during waste receipt and disposal activities 
in FY 2008. These issues are reported to the generators who then implement appropriate corrective actions to prevent recurrence.

- A shipment arrived with contamination detected on the floor of the van trailer and outside of the package. The trailer was detached from the tractor for decontamination. A Corrective Action Request was issued to the generator and the package was initially refused for disposal. The package was ultimately returned to the generator (in FY 2009).

- A shipment arrived with the bottom of the Intermodal container breached and a small amount of liquid on the trailer floor. No contamination was found and the generator was issued a Corrective Action Request and the package was repackaged and shipped back to the generator in FY 2008.

- $\quad$ Four shipments arrived missing the LLW Certification statement.

- Two shipments arrived before the electronic Package, Storage, and Disposal Request (PSDR) files were received

- $\quad$ Two packages arrived without the proper U.S. Department of Transportation marking.

- $\quad$ Shipping papers were received with Transport Indexes incorrectly assigned.

- $\quad$ A packaged received was marked with a shipping name other than what it was assigned on the shipping paper.

- A shipment arrived missing the hard-copy PSDR.

- $\quad$ Three shipments were transported prior to PSDR errors being corrected.

\subsection{EVALUATION OF SHIPPING CAMPAIGNS}

One of the 1,320 off-site inbound and none of the six off-site outbound shipments experienced incidents while in transit to/from the NTS. None of the 48 on-site transfers experienced incidents while being transported on the NTS. All generator shipping campaigns were considered successful.

\subsection{REFERENCES}

The primary sources of shipment information in this report are records kept by the NSTec Waste Management Program, who manages the NTS RWMS at Area 3 and Area 5. These records provide detailed information on each shipment of LLW and MLLW (dates received, generators, number and type of waste packages, volumes, weight, carrier, and final disposition of shipments). In addition, incident and accident information is gathered by reviewing other NSTec and NNSA/NSO correspondence and through personal communication with NNSA/NSO managers, NSTec management and program personnel, representatives from the waste generator facilities, and carrier personnel. Route information is gathered from quarterly routing reports generated by NNSA/NSO. 
The following source documents are incorporated by reference:

- $\quad$ U.S. Department of Energy, Nevada Operations Office, "Final Environmental Impact Statement for the Nevada Test Site and Off-Site Locations in the State of Nevada" DOE/EIS 0243, Las Vegas, Nevada, August 1996.

- U.S. Department of Energy, Nevada Operations Office, "Mitigation Action Plan - Final Environmental Impact Statement for the Nevada Test Site and Off-Site Locations in the State of Nevada" DOE/EIS 0243, Las Vegas, Nevada, February 1997.

- $\quad$ U.S. Department of Transportation Regulations, 49 CFR, "Transportation," Code of Federal Regulations, Office of the Federal Register, National Archives and Records Administration, U.S. Government Printing Office, Washington, DC, 1998

\subsection{POINTS OF CONTACT}

Please contact the following personnel for questions concerning the transportation of radioactive waste at the NTS or for requests for information relating to waste management and NNSA/NSO operations.

\section{WASTE MANAGEMENT}

E. Frank DiSanza, Federal Project Director

U.S. Department of Energy

National Nuclear Security Administration

Nevada Site Office

Waste Management Project

P.O. Box 98518

Las Vegas, NV 89193-8518

(702) 295-5855 


\subsection{ACRONYM LIST}

$\begin{array}{ll}\mathbf{f t}^{\mathbf{3}} & \text { Cubic Feet } \\ \mathbf{C F R} & \text { Code of Federal Regulations } \\ \mathbf{D O E} & \text { U.S. Department of Energy } \\ \mathbf{d p m} & \text { Disintegrations per minute } \\ \text { EIS } & \text { Environmental Impact Statement } \\ \text { EPA } & \text { U.S. Environmental Protection Agency } \\ \text { FY } & \text { Fiscal Year } \\ \text { LLW } & \text { Low-Level Radioactive Waste } \\ \text { MLLW } & \text { Mixed Low-Level Radioactive Waste } \\ \text { NNSA/NSO } & \text { U.S. Department of Energy, National Nuclear Security } \\ & \text { Administration Nevada Site Office } \\ \text { NRC } & \text { U.S. Nuclear Regulatory Commission } \\ \text { NSTec } & \text { National Security Technologies, LLC } \\ \text { NTS } & \text { Nevada Test Site } \\ \text { PSDR } & \text { Package, Storage, and Disposal Request } \\ \text { RWMS } & \text { Radioactive Waste Management Sites } \\ \text { TRU } & \text { Transuranic Waste } \\ \text { WIPP } & \text { Waste Isolation Pilot Plant } \\ & \\ \text { A list of generator codes can be found on page 3. }\end{array}$

\subsection{DISTRIBUTION LIST}

U.S. Department of Energy

National Nuclear Security Administration

Nevada Site Office

Technical Library

P.O. Box 98518

Las Vegas, NV 89193-8518

U.S. Department of Energy

National Nuclear Security Administration

Nevada Site Office

Public Reading Facility

c/o Nuclear Testing Archive

P.O. Box 98521

Las Vegas, NV 89193-8521

U.S. Department of Energy

Office of Scientific and Technical Information

P.O. Box 62

Oak Ridge, TN 37831-0062 